\title{
Water Relations during Ripening for Fruit of Well-watered versus Water-stressed Opuntia ficus-indica
}

\author{
Avinoam Nerd ${ }^{1}$ and Park S. Nobel ${ }^{2}$ \\ Department of Organismic Biology, Ecology, and Evolution, University of California, Los Angeles, \\ CA 90095-1606
}

ADDITIONAL INDEX WORDS. fruit growth, stomata, sugars, transpiration, water deficit, water vapor conductance, prickly pear cactus

\begin{abstract}
Aвstract. Water relations and fruit development were studied for up to 100 days after anthesis for potted plants of $O p u n t i a$ ficus-indica (L.) Mill. (a prickly pear) that were either well-watered or water-stressed, each plant consisting of a medium-sized cladode bearing two or three fruit. Even though cladodes of water-stressed plants lost up to $50 \%$ of their thickness, their fruit continued to gain water and to develop; at ripening such fruit had only $16 \%$ less water than fruit of watered plants. Maturation indicated by the decrease in fractional peel content and increases in pulp weight and in pulp soluble sugar content was hastened by water stress, leading to ripening $\approx \mathbf{8 8}$ days after anthesis for water-stressed plants, which was 10 days earlier than for watered plants. Fruit had a lower stomatal frequency than the cladodes but both exhibited Crassulacean acid metabolism behavior. Transpiration occurred mainly at night, and the daily amount of water transpired per unit fruit surface area decreased with time, especially for fruit of water-stressed plants. This decrease was related to fruit expansion (leading to decreased stomatal frequency) for watered plants and to both fruit expansion and water stress for water-stressed plants. At 75 days after anthesis, daily diameter changes of fruit were correlated with transpiration, contraction occurring at night and expansion during the daytime, and changes were greater for watered plants for which daily transpiration was higher.
\end{abstract}

Opuntia ficus-indica (a prickly pear) is a highly productive cactus widely cultivated for its fruit in subtropical areas of Mexico, the Mediterranean basin, and South Africa (Nobel, 1988; Mizrahi et al., 1997). The fruit is an epigynous medium-sized berry (100 to 150 g) developing from both the ovary of the flower and the receptacle that surrounds the ovary (Nerd and Mizrahi, 1997). Fruit of O. ficusindica have three distinct developmental stages: size increases in the first and the last stages but is slowed in the middle stage during which seed development is completed. Maturation, characterized by a decrease of peel content, increase of pulp content, and accumulation of sugars in the pulp, occurs during the last stage (Cantwell, 1995; Nerd and Mizrahi, 1997). Fruit are ripe at the beginning of peel color development, which is the optimal time for harvest.

The weight of newly set fruit of $O$. ficus-indica is relatively high, about one-third of the weight of a mature fruit. Most of the weight of a young fruit is contributed by the peel, which originates from the receptacle (Nerd and Mizrahi, 1997). Similar to the flattened stem segments (cladodes), the peel is succulent and exhibits crassulacean acid metabolism (CAM), although the contribution of $\mathrm{CO}_{2}$ uptake by the peel to fruit dry matter is small (only $11 \%$ for young fruit and negligible during maturation; Inglese et al., 1994). Indeed, based on the water potential gradient between a cladode and fruit, most of the assimilates as well as water are imported into the fruit via the phloem (Nobel et al., 1994; Wang and Nobel, 1995; Wang et al., 1997). Less is known about the water relations of fruit and their sensitivity to drought. Growers in countries with dry summers, such as Israel or Sicily, irrigate $O$. ficus-indica during fruit growth, particularly at the last stage (maturation), assuming that application of water increases

Received for publication 25 Oct. 1999. Accepted for publication 20 June 2000 This research was supported by the University of California, Los Angeles-Ben Gurion Program of Cooperation through the generous gift of Sol Leshin. Discussions with Edward Bobich and Erick De la Barrera are gratefully acknowledged. The cost of publishing this paper was defrayed in part by the payment of page charges. Under postal regulations, this paper therefore must be hereby marked advertisement solely to indicate this fact.

${ }^{1}$ Present address: Institutes for Applied Research, Ben Gurion University of the Negev, Beer Sheva 84105, Israel.

${ }^{2}$ To whom reprint requests should be addressed; e-mail psnobel@ biology.ucla.edu. fruit weight (Inglese, 1995). However, because water stored in the inner cladode tissues can be used during drought (Nobel, 1988) and because fruit have a considerable peel mass at the beginning of the last stage (Cantwell, 1995), it is hypothesized that fruit may mature successfully to a similar size and quality even when water stress is imposed during the last stage of development. Thus, the water relations of cladodes and fruit were investigated for potted plants of $O$ ficus-indica that were well-watered or water-stressed during the last stage of fruit development.

\section{Materials and Methods}

Plant material. Terminal cladodes with newly initiated flower buds were harvested at the beginning of March 1999 from a prickly pear cactus (Opuntia ficus-indica) (accession number 1279 from Texas A \& M Univ., Kingsville) growing at the Agricultural Research Station, University of California, Riverside. The cladodes were $37 \pm 3 \mathrm{~cm}$ long, $21 \pm 2 \mathrm{~cm}$ wide, and $2.0 \pm 0.1 \mathrm{~cm}$ thick. After the cut surface of the cladodes had dried for 3 weeks, the cladodes were planted in $1.5-\mathrm{L}$ pots containing a loamy soil (Arlington loam, ApB) from the Agricultural Research Station and maintained in a greenhouse. Average daily maximum/minimum air temperatures in the greenhouse were $25 / 14^{\circ} \mathrm{C}$ for March to June and $28 / 16^{\circ} \mathrm{C}$ for July and early August 1999; maximum/minimum relative humidities averaged $75 \% / 40 \%$. The plants were irrigated twice weekly with half-strength Hoagland solution (Hoagland and Arnon, 1950) until drainage occurred from the pots. Root initiation began immediately after planting. Flowers opened from mid-April to mid-May and were hand pollinated with their own pollen on the day of opening, leading to the setting of two or three fruit per plant. Two groups of 15 plants each that flowered at the beginning of May were selected from 20 to 25 June ( $\approx 50 \mathrm{~d}$ after anthesis); water was applied every other day to one group and was withheld from the other group. The seedcoats became dark, indicating seed maturation, by midJune.

Measurements. Fruit length, diameter at midfruit, and thickness at midcladode were measured every 6 to $9 \mathrm{~d}$ with calipers for six 
randomly selected plants of each group (one fruit per plant). Changes in cladode thickness in $O$. ficus-indica indicate changes in cladode water content $(r=0.95)$, and the percentage of decline in thickness approximates the percentage water loss (day and night variations in water content were minimal for this succulent stem). Stomatal frequency was determined for epidermal peels from midcladode or from the lower, middle, and upper parts of fruit at the beginning of maturation (65 to $70 \mathrm{~d}$ after anthesis) or near the end of maturation ( 85 to $90 \mathrm{~d}$ after anthesis). For each sample, stomata were counted in three fields (area of $3.83 \mathrm{~mm}^{2}$ each) using a light microscope (BH2; Olympus, Lake Success, N.Y.).

Transpiration of fruit and cladodes was measured from $70 \mathrm{~d}$ after anthesis to fruit ripening, indicated by the development of a purple peel color, at up to $100 \mathrm{~d}$ after anthesis using a steady-state porometer (LI-1600; LI-COR, Lincoln, Nebr.). The top of the cuvette was replaced by an acrylic plate with a $3.0 \times 1.5-\mathrm{cm}$ opening whose margin was covered with a 4-mm-thick foam-rubber gasket to achieve a good seal with the cladode or fruit surface. Measurements were made every $4 \mathrm{~h}$ over 24 -h periods at midcladode or midfruit under each treatment. Instantaneous values of fruit transpiration were integrated to obtain daily fruit transpiration. Fruit area was calculated from length and diameter, assuming that a fruit is a prolate spheroid (formed by the rotation of an ellipse about its major axis). Instantaneous changes in fruit diameter $75 \mathrm{~d}$ after anthesis were measured over 24-h periods with an electromechanical transducer (E-Line LVDT; Shaevitz Engineering, Pennsaunken, N.J.) clamped at midfruit. Output from the transducer was recorded using a G-1000 chart recorder (Varian, Palo Alto, Calif.).

Fruit were harvested periodically $50 \mathrm{~d}$ after anthesis to fruit ripening. Peel and pulp were separated, weighed, and weighed again after drying at $70{ }^{\circ} \mathrm{C}$ to determine water content. Sugars were analyzed in dry samples of ground peel $(50 \mathrm{mg})$ or pulp $(300 \mathrm{mg}$, ground gently to avoid seed breaking), except for ripe fruit for which crushed fresh pulp ( $2 \mathrm{~g})$ was used. Soluble sugars were extracted with $80 \%$ ethanol and measured by a phenol-sulfuric acid method (Dubois et al., 1956).

STATISTICAL ANALYSIS. Regression analysis, analysis of variance (ANOVA), and comparisons between means (Fisher's protected least significant difference) were performed with StatView 4.0 (Abacus Concepts, Berkeley, Calif.) software.

\section{Results}

At $50 \mathrm{~d}$ after anthesis, when water was withheld from plants in the water-stress treatment, cladode thickness averaged $18 \mathrm{~mm}$ and fruit were at the beginning of the last growth stage, which followed the intermediate lag stage (Fig. 1A and B). Water stress caused a continuous decrease in cladode thickness (by $0.4 \mathrm{~mm} \cdot \mathrm{d}^{-1}$ ) and hastened fruit ripening, indicated by the appearance of a purple peel color. Regression lines for cladode thickness y (in $\mathrm{mm}$ ) versus time $\mathrm{x}$ (in days) for well-watered (w-w) and water-stressed (w-s) plants were as follows: $\mathrm{y}(\mathrm{w}-\mathrm{w})=17.8+0.04 \mathrm{x}\left(r^{2}=0.56^{*}\right) ; \mathrm{y}(\mathrm{w}-\mathrm{s})=29.1$ $-0.21 \mathrm{x}\left(r^{2}=0.96^{* *}\right)$. The time from anthesis to ripening averaged 88 $\pm 2 \mathrm{~d}$ for water-stressed plants versus $98 \pm 2 \mathrm{~d}$ for well-watered plants (mean \pm SE for $\mathrm{n}=12$ plants; $P<0.05$ ). Regression coefficients for fruit length or diameter versus time from $50 \mathrm{~d}$ after anthesis to the beginning of peel color change did not differ significantly $(P>0.05)$ between well-watered and water-stressed plants. Thus, the smaller size of mature fruit of water-stressed plants can be attributed mainly to their shorter growth period. The ratio between current cladode thickness and the maximal thickness measured for well-watered plants (an estimate of cladode relative water content) at the time of fruit ripening was 0.95 for well-watered plants and 0.45 for waterstressed plants $(P<0.01)$.

Daily transpiration per unit surface area at $65 \mathrm{~d}$ after anthesis was $\approx 18 \mathrm{mmol} \cdot \mathrm{m}^{-2} \cdot \mathrm{d}^{-1}$ for cladodes and fruit of both well-watered and water-stressed plants (Fig. 2). Daily transpiration during the last growth stage decreased in cladodes and fruit of water-stressed plants and was significantly lower $(P<0.05)$ than in well-watered plants (two factor ANOVA). Daily transpiration for well-watered plants fluctuated about the initial level for the cladodes and tended to decrease for the fruit; a significant difference $(P<0.01)$ between cladodes and fruit occurred at ripening. At ripening, daily transpiration had decreased $\approx 40 \%$ for fruit of well-watered plants and $60 \%$ for fruit and $50 \%$ for cladodes of water-stressed plants while remaining essentially unchanged for cladodes of well-watered

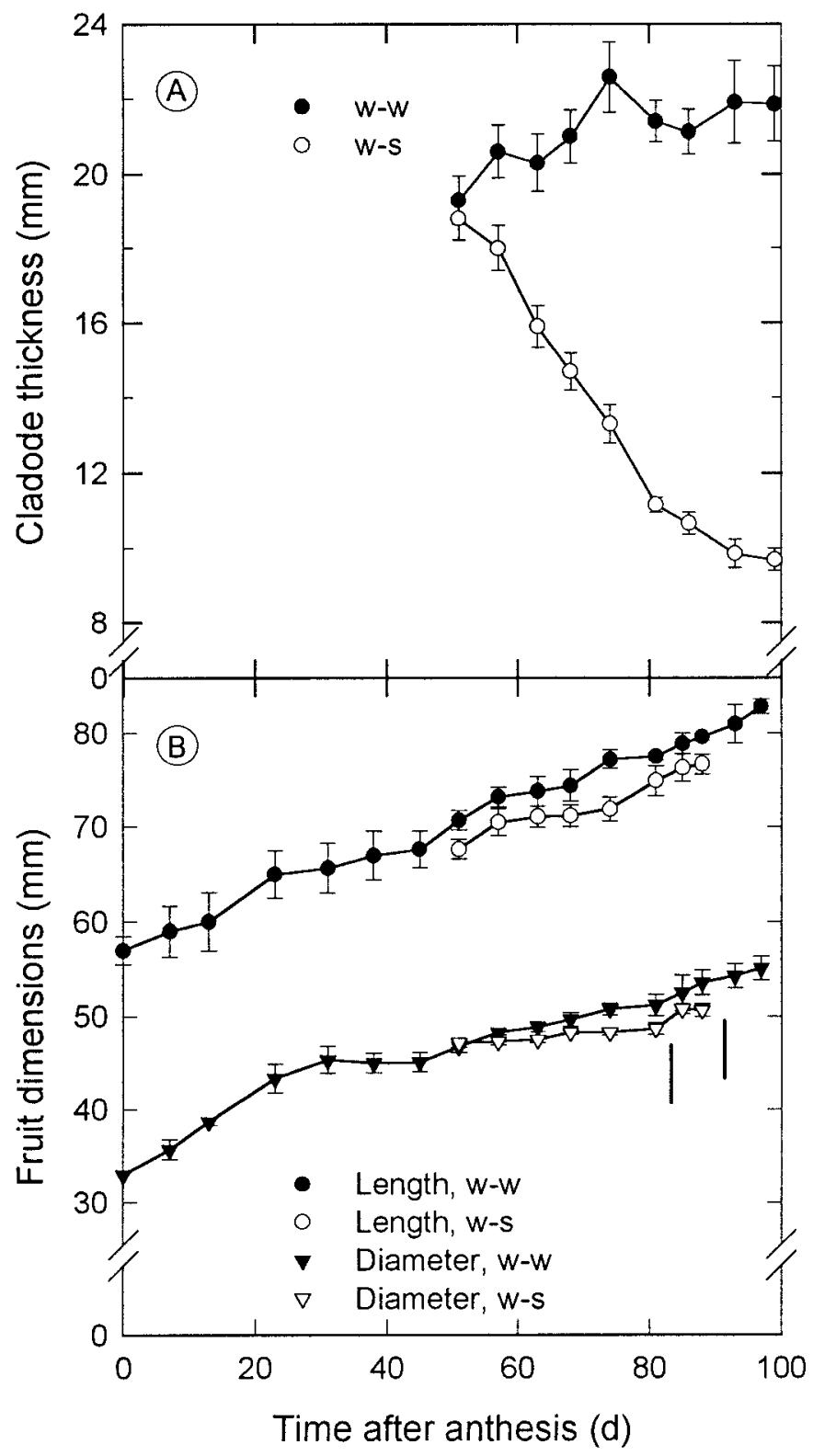

Fig. 1. (A) Thickness at midcladode for well-watered (w-w) and water-stressed (w-s) plants from the time of water withholding and (B) fruit length and diameter from anthesis for well-watered plants and from the time of water withholding for water-stressed plants, both up to fruit ripening. Vertical bars in B delimit the beginning of peel color change, indicating fruit maturation. Data are means $\pm \mathrm{SE}$ $(\mathrm{n}=6$ plants $)$ 


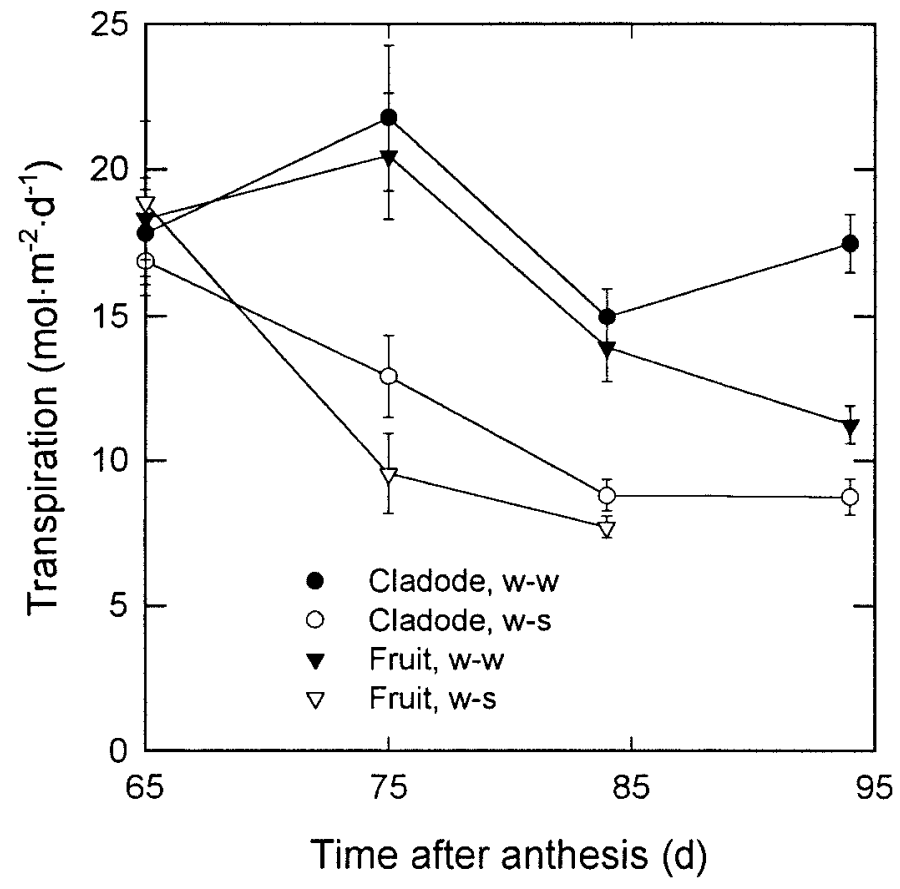

Fig. 2. Total daily transpiration per unit surface area for cladodes or fruit from 65 $\mathrm{d}$ after anthesis to the beginning of peel color change in well-watered $(\mathrm{w}-\mathrm{w})$ and water-stressed (w-s) plants. Data are means \pm SE $(n=6$ plants $)$.

plants (Fig. 2). Using a fruit surface area estimated from fruit length and diameter, the calculated daily transpiration per fruit at $65 \mathrm{~d}$ after anthesis was $144 \mathrm{mmol} /$ fruit for both treatments (fruit averaged 85 $\mathrm{cm}^{2}$ in surface area). A similar daily transpiration rate per fruit was determined for mature fruit of well-watered plants $\left(120 \mathrm{~cm}^{2}\right.$ in surface area), but for those of water-stressed plants $\left(109 \mathrm{~cm}^{2}\right.$ in surface area $)$, the daily transpiration per fruit was $50 \%$ lower $(P<0.05)$.

Transpiration for both cladodes and fruit occurred mainly at night, and its instantaneous rate was correlated with the water vapor (stomatal) conductance (Fig. 3A). Conductance was maximal near midnight and minimal near noon and was lower for water-stressed plants than for well-watered plants, especially for the fruit (at the time of maximal water vapor conductance, the LSD at $P<0.05$ was $\left.7.1 \mathrm{mmol} \cdot \mathrm{m}^{-2} \cdot \mathrm{s}^{-1}\right)$. For the relationship between fruit diameter $\mathrm{y}$ (in $\mathrm{mm}$ ) and time elapsed from 1400 to $0300 \mathrm{HR}$ (Fig. 3B) for the wellwatered $(\mathrm{w}-\mathrm{w})$ and water-stressed (w-s) conditions, the following equations were derived: $\mathrm{y}(\mathrm{w}-\mathrm{w})=0.0892-0.0406 \mathrm{x}+0.017 \mathrm{x}^{2}\left(r^{2}\right.$ $=0.75) ; \mathrm{y}(\mathrm{w}-\mathrm{s})=0.014 \mathrm{x}\left(r^{2}=0.57\right)$. Fruit of well-watered plants contracted at night and expanded during the day with a diameter amplitude of $0.27 \mathrm{~mm}$, whereas fruit of water-stressed plants had only small daily diameter changes (Fig. 3B). Assuming that the contraction was uniform for the whole fruit, the calculated daily water loss per fruit $\left(98 \mathrm{~cm}^{2}\right.$ in surface area) of well-watered plants was $2.7 \mathrm{~g} /$ fruit, consistent with that of daily transpiration at that time (Fig. 2).

Stomatal frequency (number of stomata per square millimeter) increased from the lower to the upper parts of a fruit and decreased during fruit growth as the fruit surface area expanded (Table 1). Regression analysis for the relationship between stomatal frequency (y) and the distance in $\mathrm{mm}(\mathrm{x})$ of stomata from the base of the fruit gave $\mathrm{y}=0.99+0.81 \mathrm{x}\left(r^{2}=0.99^{*}\right)$ for fruit at 65 to $70 \mathrm{~d}$ after anthesis and $\mathrm{y}=0.41+0.54 \mathrm{x}\left(r^{2}=0.96^{*}\right)$ for fruit at 85 to $90 \mathrm{~d}$ after anthesis. Stomatal frequency in the upper part of a fruit at 65 to 70 $\mathrm{d}$ after anthesis is comparable to that at the middle of a cladode (average of $46 / \mathrm{mm}^{2}$ ).

During the last stage of fruit development, the peel fresh weight per fruit was $13 \%$ greater for fruit of well-watered plants compared to water-stressed plants, but remained constant while pulp weight increased significantly $(P<0.05$; Fig. 4A). In particular, pulp weight increased by $2.8 \mathrm{~g} \cdot \mathrm{d}^{-1}$ for well-watered plants and by $3.4 \mathrm{~g} \cdot \mathrm{d}^{-1}$ for water-stressed plants, commencing at $70 \mathrm{~d}$ after anthesis and continuing until peel weight and pulp weight were almost equal, which occurred at $88 \mathrm{~d}$ after anthesis for water-stressed plants and $10 \mathrm{~d}$ later for well-watered plants (Fig. 4A). Fruit of water-stressed plants had a peel color change and reached a commercial weight at ripening $(118 \pm 3 \mathrm{~g})$ that was lower $(P<0.05)$ than for fruit of wellwatered plants $(137 \pm 6 \mathrm{~g})$. Peel thickness declined in parallel with the increase in pulp weight (Fig. 4B). At fruit ripening, the peel of fruit of water-stressed plants was intact while that of fruit of wellwatered plants had superficial cracks that were 3 to $5 \mathrm{~mm}$ long. As the pulp weight increased during the final stage of fruit maturation, the water content decreased slightly in the peel but increased substantially ( $5 \%$ to $7 \% ; P<0.05$ ) in the pulp (Fig. 4C). Soluble sugars accumulated in the peel and especially the pulp beginning at $70 \mathrm{~d}$ after anthesis (Fig. 4D). Concentrations of soluble sugars on a dry weight basis were similar for ripe fruits of well-watered and water-stressed plants, averaging $14.9 \pm 1.2 \%$ for the peel and 18.3 $\pm 1.2 \%$ for the pulp $(P>0.05)$.

\section{Discussion}

Depending on species, water stress can hasten or delay fruit ripening and can influence fruit quality (Kaufman, 1972; Mills et al., 1994; Pomper and Breen, 1997; Poni et al., 1994; Yakushiji et al., 1996). The present study indicates that water stress leading to a water deficit in the cladodes of $O$. ficus-indica during the last stage of fruit development induced early ripening of the fruit but had only small effects on fruit characteristics, e.g., the fruit were smaller than those of well-watered plants.

Fruit of $O$. ficus-indica are a strong sink for water and dry matter (Inglese et al., 1994; Nobel et al., 1994). Indeed, fruit of waterstressed plants gained water and continued to grow until they reached a considerable weight even though the underlying cladodes continuously lost water, amounting to $50 \%$ of their water content at the time water was withheld from the plants. Based on pressurevolume curves (tissue water potential plotted vs. tissue relative water content) obtained for cladodes of water-stressed plants of $O$. ficus-indica leading to the same decline in cladode water content (Goldstein et al., 1991), the estimated water potential of the cladodes

Table 1. Stomatal frequency for upper, middle, and lower parts of fruit (at a distance of 50-60, 35-40, and 20-25 mm, respectively, from the base of the fruit) of well-watered plants at the beginning and the end of the last stage of fruit growth. Values are means \pm SE ( $n=6$ plants).

\begin{tabular}{|c|c|c|c|c|}
\hline $\begin{array}{l}\text { Time after } \\
\text { anthesis }\end{array}$ & $\begin{array}{l}\text { Surface } \\
\text { area }\end{array}$ & \multicolumn{3}{|c|}{$\begin{array}{l}\text { Stomatal frequency } \\
\left(\text { number } / \mathrm{mm}^{2}\right)\end{array}$} \\
\hline (d) & $\left(\mathrm{cm}^{2}\right)$ & Upper & Middle & Lower \\
\hline $65-70$ & $80 \pm 3$ & $45.7 \pm 3.2$ & $28.3 \pm 0.9$ & $21.8 \pm 0.9$ \\
\hline $85-90$ & $105 \pm 3$ & $32.7 \pm 2.1$ & $19.0 \pm 1.8$ & $14.2 \pm 2.0$ \\
\hline
\end{tabular}


was -1.2 MPa. Under well-watered conditions in the laboratory and the field, the water potential for developing fruits and mature cladodes is about -0.4 MPa (Goldstein et al., 1991; Nobel et al., 1994). The ability of the fruit to accumulate water when the cladodes experience such water stress supports the finding that water is imported into the fruit of $O$. ficus-indica by the phloem and not by the xylem, the latter requiring a decreasing water potential from the cladode to the fruit (Nobel et al., 1994). Moreover, the phloem sap for $O$. ficus-indica is extremely dilute, $350 \mathrm{mOsm}$, compared with that for other species, $\approx 900$ mOsm (Wang and Nobel, 1995; Wang et al., 1997). Because peel and cladode tissues have a high water capacitance (change in relative water content divided by change in tissue water potential), the peel could supply water to the rapidly growing pulp (Nobel et al., 1994), consistent with the observed decrease in peel thickness accompanying pulp growth. However, the amount of water in the peel and the peel weight actually remain

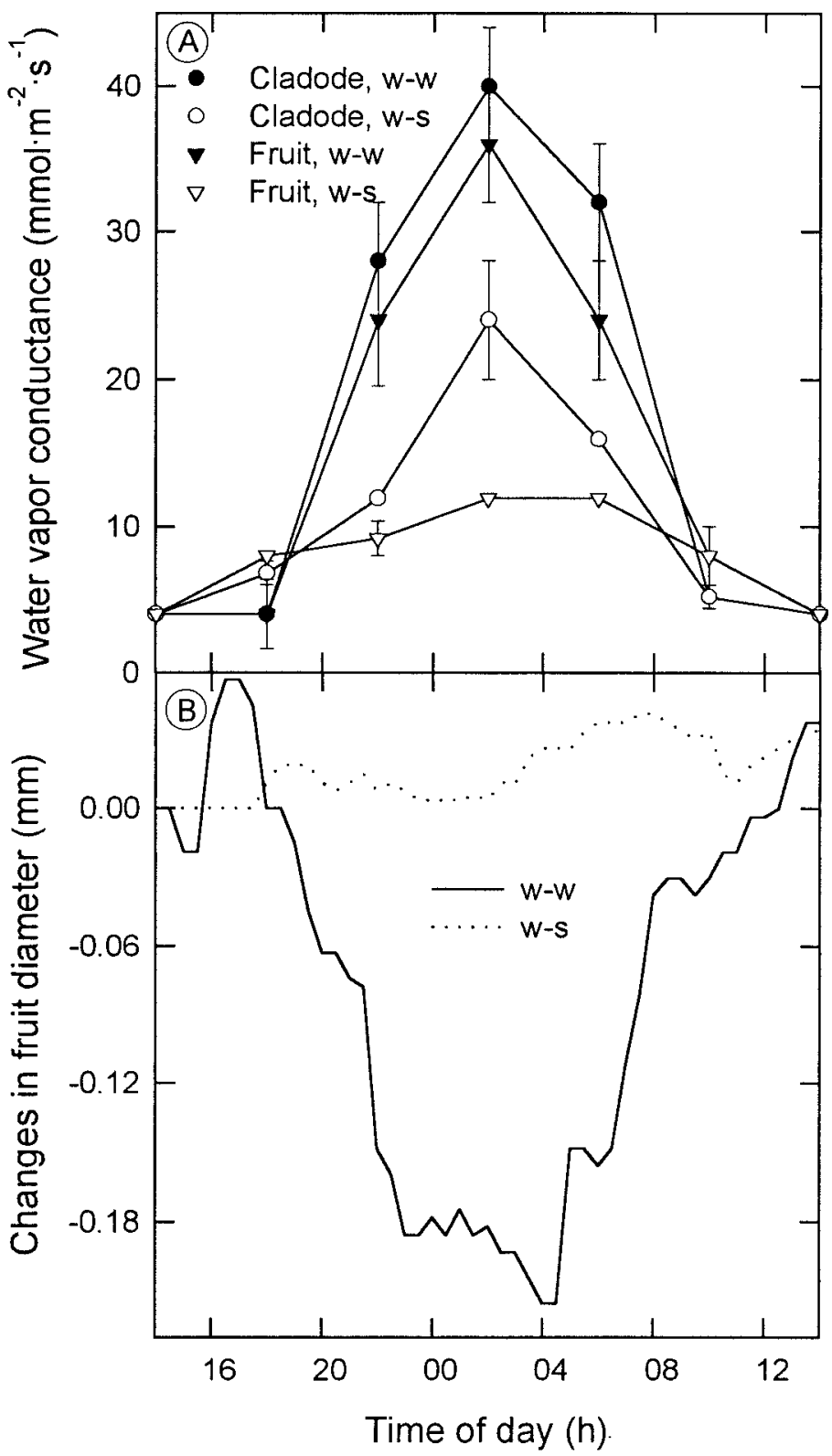

Fig. 3. (A) Water vapor conductance for cladodes and fruit of well-watered (ww) and water-stressed plants (w-s) and (B) representative diameter changes for fruit from a well-watered plant and a water-stressed plant. Data were obtained over 24-h periods at $75 \mathrm{~d}$ after anthesis $(n=6$ plants for A). fairly constant during maturation for fruit of both well-watered and water-stressed plants. Thus, pulp water must be supplied by the underlying cladode, and the decrease in peel thickness is mainly the

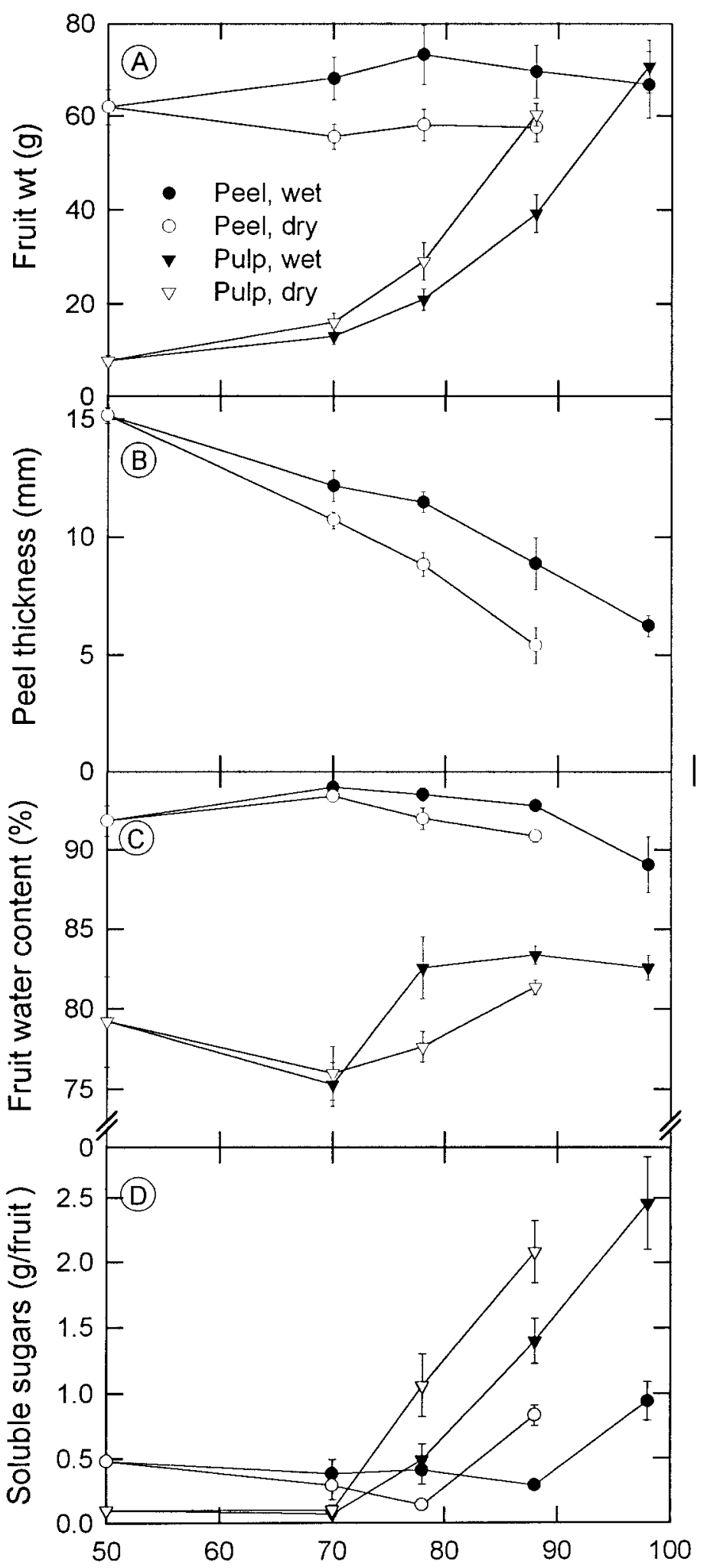

Fig. 4. Characteristics of fruit of well-watered and water-stressed plants during maturation, indicating (A) peel and pulp fresh weight, (B) peel thickness at midfruit, (C) percent water in peel and pulp, and (D) soluble sugars in the fruit. Data are means \pm SE $(n=6$ plants $)$. 
outcome of peel stretching resulting from the pressure developed by the growing pulp. In contrast, no peel expansion occurs during maturation in vine cactus [Selenicereus megalanthus (Scum. ex Vaupel) Moran] fruit (pitaya type; Nerd and Mizrahi, 1998).

The fruit tended to have a lower stomatal frequency than the cladodes (averaging $23 / \mathrm{mm}^{2}$ at midfruit vs. twice that at midcladode) but with a similar pattern of daily water vapor conductance changes indicating CAM behavior, as stomatal opening occurred mainly at night. A decrease in stomatal frequency in the expanding fruit can explain the decrease in transpiration per unit surface area with time for fruit of well-watered plants, although transpiration per fruit did not change appreciably. In contrast, transpiration per fruit decreased with time for water-stressed plants, reflecting a decrease in stomatal conductance as a result of water stress. Because a decrease in water content in water-stressed plants occurred only for the cladodes, a signal from the cladodes, such as abscisic acid (ABA) which is known to be a water stress signal and can be transported in sap of both the xylem and the phloem (Taiz and Zeiger, 1991), may have affected peel stomatal conductance. ABA is transported from leaves to the ripening berry in the phloem of grape (Vitis vinifera L.) (Shizaki et al., 1999), and levels of phloem-mobile ABA are elevated under salinity or water stress for castor bean (Ricinus communis L.) (Jeschke et al., 1997; Zhong et al., 1996). Therefore, phloem transport of ABA from the cladodes to fruit seems probable for $O$. ficus-indica.

Daily changes in fruit diameter at $75 \mathrm{~d}$ after anthesis were substantial for fruit of well-watered plants of $O$. ficus-indica but small for fruit of water-stressed plants and were correlated with fruit transpiration. The decreased diameter change for fruit of waterstressed plants indicated that water did not flow out of the fruit, as occurs for developing fruit of grape (Greenspan et al., 1996) and strawberry (Fragaria $\mathrm{H}$ ananassa Duchesne) (Pomper and Breen, 1997) for which daily fruit contraction increases in watered-stressed plants. The advanced fruit maturity in water-stressed plants of $O$. ficus-indica was reflected in early accumulation of soluble sugars in both pulp and peel, although the soluble sugar concentration (dry weight basis) was similar for ripe fruit of water-stressed and wellwatered plants. Under certain water-stress conditions, fruit of stressed plants accumulate more sugars than nonstressed plants, and osmoregulation is involved in sugar accumulation for some plants (Kaufman, 1972; Mills et al., 1994; Pomper and Breen, 1997; Yakushiji et al., 1996). Net $\mathrm{CO}_{2}$ uptake by the underlying cladode of the water-stressed plants may be so low that the supply of carbon to the fruit may not allow higher sugar accumulation. How fruit load (the relationship between fruit number to the total surface area of the underlying cladodes) affects sugar content in the fruit (as well as other fruit characteristics) should be determined for water-stressed O. ficus-indica. In this regard, sugar accumulation in water-stressed grape decreases as fruit load increases (Poni et al., 1994).

Obtaining out-of-season crops that command high prices increases the profitability for cultivating $O$. ficus-indica in the Mediterranean region (Inglese, 1995; Mizrahi et al., 1997). Growers in Israel tend to harvest only the early fruit of the summer crop, while the rest is left because of low prices. Several methods, such as flower removal that induces a second bloom or application of water and fertilizer after harvest of the summer crop, help obtain late crops for O. ficus-indica, but little is known about how to produce an early crop (Nerd and Mizrahi, 1997). A selective flower thinning that leaves only the oldest flowers of the spring flush combined with no irrigation at a late stage of fruit development may allow production of earlier summer crops. Field studies are needed to determine the optimal fruit load for high quality fruit under water stress.

\section{Literature Cited}

Cantwell, M. 1995. Post-harvest management of fruits and vegetable stems, p. 120-136. In: G. Barbera, P. Inglese, and E. Pimienta-Barrios (eds.). Agro-ecology, cultivation and uses of cactus pear. United Nations Food Agr. Org., Rome.

Dubois, M., K.A. Gilles, J.K. Hamilton, P.A. Rebers, and F. Smith. 1956. Calorimetric method for determination of sugars and related substances. Anal. Chem. 28:350-356.

Goldstein, G., J.L. Andrade, and P.S. Nobel. 1991. Differences in water relation parameters for the chlorenchyma and the parenchyma of Opuntia ficus-indica under wet versus dry water conditions. Austral. J. Plant Physiol. 18:95-107.

Greenspan, M.D., H.R. Scultz, and M.A. Mattews. 1996. Field evaluation of water transport in grape berries during water deficits. Physiol. Plant. 97:55-62.

Hoagland, D.R. and D.I. Arnon. 1950. The water-culture method for growing plants without soil. Calif. Agr. Expt. Sta. Circ. 347:1-32.

Inglese, P. 1995. Orchard planting and management, p. 78-91: In: G. Barbera, P. Inglese, and E. Pimienta-Barrios (eds.). Agro-ecology, cultivation and uses of cactus pear. United Nations Food Agr. Org., Rome.

Inglese P., A.A. Israel, and P.S. Nobel. 1994. Growth and $\mathrm{CO}_{2}$ uptake for cladodes and fruit of the Crassulacean acid metabolism species Opuntia ficus-indica during fruit development. Physiol. Plant. 91:708-714.

Jeschke, W.D., A.D. Peuke, J.S. Pate, and W. Hartung. 1997. Transport, synthesis and catabolism of abscisic acid (ABA) in intact plants of castor bean (Ricinus communis L.) under phosphate deficiency and moderate salinity. J. Expt. Bot. 48:1737-1747.

Kaufmann, M. R. 1972. Water deficit and reproductive growth, p. 91-124. In: T. T. Kozlowski (ed.). Water deficit and plant growth. vol. 3. Academic Press, New York.

Mills, T.M., M.H. Behboudian, P.Y. Tan, and B.E. Clotier. 1994. Plant water status and fruit quality in 'Braeburn' apples. HortScience 29:12741278.

Mizrahi, Y., A. Nerd, and P.S. Nobel. 1997. Cacti as crops. Hort. Rev. 18:291-319.

Nerd, A. and Y. Mizrahi. 1997. Reproductive biology of cactus fruit crops. Hort. Rev. 18:321-346.

Nerd, A. and Y. Mizrahi. 1998. Fruit development and ripening in yellow pitaya. J. Amer. Hort. Sci. 123:560-562.

Nobel, P.S. 1988. Environmental biology of agaves and cacti. Cambridge Univ. Press, New York.

Nobel, P.S., J.L. Andrade, N. Wang, and G.B. North. 1994. Water potentials for developing cladodes and fruits of a succulent plant, including xylem-versus-phloem implications for water movement. J. Expt. Bot. 45:1801-1807.

Pomper, K. and P.J. Breen. 1997. Expansion and osmotic adjustment of strawberry fruit during water stress. J. Amer. Soc. Hort. Sci. 122:183189.

Poni, S., A.N. Lasko, J.R. Turner, and R.E. Melios. 1994. Interaction of crop level and late-season water-stress on growth and physiology in fieldgrown concord grapevines. Amer. J. Enol. Viticult. 45:252-258.

Shizaki, S., Y. Kamata, T. Ogata, S. Horiuchi, and K. Kawase. 1999. Localization of abscisic acid in grape berry by immunohistochemical technique. J. Jpn. Soc. Hort. Sci. 68:1-9.

Taiz, L. and E. Zeiger. 1991. Plant physiology. Benjamim/Cummings, Redwood City, Calif.

Wang, N. and P.S. Nobel. 1995. Phloem exudate collected via scale insect stylets for the CAM species Opuntia ficus-indica under current and doubled $\mathrm{CO}_{2}$ concentrations. Ann. Bot. 75:525-532.

Wang, N., H. Zhang, and P.S. Nobel. 1997. Phloem-xylem water flow in developing cladodes of Opuntia ficus-indica during sink-to-source transition. J. Expt. Bot. 48:675-682.

Yakushiji, H., H. Nonami, T. Fukuyama, S. Ono, N. Takagi, and Y. Hashimoto. 1996. Sugar accumulation enhanced by osmoregulation in satsuma mandarin fruits. J. Amer. Soc. Hort. Sci. 121:466-472.

Zhong, W., W. Hartung, E. Komer, and C. Schobert. 1996. Phloem transport of abscisic acid in Ricinus communis L. seedlings. Plant Cell Environ. 19:471-477. 